\title{
Social Theory and Everyday Marxists: Russian Perspectives on Epistemology and Ethics
}

\author{
ANNA KRUGLOVA \\ National Research University Higher School of Economics, Moscow
}

\section{IN TR O DUCTION}

Many would agree that ideas and ideals about what constitutes a just, wellworking society matter as much as what takes place within it. Centuries of reflective effort on what an ideal society should resemble or avoid have transformed the world to the same if not larger degree than advances in physics or chemistry. In recent decades, many have also realized that these ideas are not confined, either in practice or concern, to the ivory towers or more elegant classes. People of various standings and dispositions share these theories of the social, "downloading" them "as effectively as they do MP3 files" (Latour 2005: 231), and using them to define where they stand, who they are, who they should take into account, how they should justify themselves, and to what forces they are allowed to bend.

The metaphor of an $\mathrm{mp} 3$ file is unfortunate, though. We rarely manipulate or transform mp3 files to the same degree that we manipulate ideas, not only sharing but also co-producing the "recordings," if only by mixing the tracks in our own compositions. The concern of the present paper is, however, only in part with the increasingly motley origins of cultural production. Despite the variations, there is one particular track that, as I see it, is still worth

Acknowledgments: This paper is based on research conducted with generous support from the University of Toronto, the Social Sciences and Humanities Research Council of Canada, an Ontario Graduate Scholarship, and the Wenner-Gren Foundation for Anthropological Research. For making the article better through their thoughtful comments, I am grateful to Michael Lambek, Ivan Kalmar, Bruce Grant, Donna Young, Nikolay Ssorin-Chaikov, Douglas Rogers, Natalia Roudakova, Maria Sidorkina, Andrei Tutorski, Dmitry Oparin, and Konstantin Gaaz. I owe a special debt to Gavin Smith, whose course on Marxism made me, for the first time, puzzle over how Pierre Bourdieu's theoretical ideas would, and would not, work in the Russian context. 
identifying as particular, if only for analytical purposes. In the overall jazz of cultural history, Marxian theories in Russia have topped all the mp3 charts for nearly a century. Yet, I will maintain in this essay, basic sociological and philosophical approaches to Russian Marxism have never aspired to understand this "Marxian file" and its popularity. Now, in what can be seen as postpostsocialist times, such an effort might seem to be in the vein of "salvage anthropology." It is not so. The melody — or, perhaps, the ding of Marxismcontinues to sound in the changing everyday narratives in Perm, one of fifteen cities in Russia with a population over one million. My studies over a number of years and a closer reading of ordinary talk convinced me that Russian/Soviet Marxism should be studied by anthropologists in the same manner, if not to the same degree, that "neoliberalism" is studied today. But this investigation will never start properly if we do not stop looking at Marxism as "just" an ideology or even a philosophy, and rediscover Marxism as it has evolved, and continues to evolve, as a form of Gramscian hegemony. To clarify this approach, I also propose a view of Marxism as a vernacular: as a process in which "canonical" or "official" Marxism-Leninism, sifted as it was through ideological and disciplinary sieves, became a vernacular version of itself when it was further modified by a broad range of people who used it to build, explain, and make sense of their ordinary worlds. ${ }^{1}$

What do we get if we stop looking at Russian Marxism from the usual taxidermist's perspective and elevate it to a continuing, hegemonic form? First, it will bring a new line of insights to our understanding of Russian everyday worlds. The ethnographic scenes that I present in this essay, and their Marxian interpretations, indicate that most people in Russia today are much more active and politically engaged than most observers have been giving them credit for. That said, they perform a different kind of politics, one more prolix and routine, full of debate, and far more interesting than (but not exclusive to) what often occurs on the federal stage. ${ }^{2}$ Second, it will show us what can be called the everyday (after)life of our social theories. But most importantly, Russian Marxism is particularly suited to showcasing how self-aware we should be about the fact that "our" social theories and "folk" social theories are not similar just because of some human universal; they are literally and historically derived from the same thinkers. Because of that, a certain recursiveness plagues an anthropologist in Russia, a difficulty that, as more voices are noticing, is not exclusive to Russia (Moore 2009). Therefore, even if we study Marxism as a form of hegemony, it will remain a topic of particular

\footnotetext{
1 Predictably, this perspective renders irrelevant questions of whether Russian Marxism has been "vulgar," "mechanical," or similar or dissimilar to "European" or any other Marxism. I will also have to leave aside the social history of changes in Marxism in Russia, which, although relevant, has yet to be explored by historians (though see Nemtzev 2015).

2 See also Clément 2015, on the "ordinariness" of Russian political mobilizations.
} 
ethical and epistemological awkwardness, which usually goes completely unnoticed, and which I will attempt to flesh out in this essay.

The article consists of two parts. First, I will compare some influential perspectives on ways to theorize what can arguably be defined as the work of "ideology" in Soviet Union/Russia, and explicate what I mean by the necessity to view Marxism as a hegemony and a vernacular. In doing this, I will also exemplify what I call the recursive effects of vernacular Marxism vis-à-vis anthropological theory, by showing how the very notion of "ideology" is not (only) a clean and detached analytical tool, but also a local ethical and ontological concept that elicits visceral reactions. The difficulties of recursivity will not disappear, even if we use "ideology" in arguably more de-ideologized ways, such as the concept of "semiotic ideology" (Keane 2007), or my own suggestion of "hegemony."

The second part will further demonstrate how the hegemonic effects of Marxism play out today in everyday narratives among my medium-income, middle-aged, ordinarily educated informants living in a provincial center, and the difficulties of recursivity that arise when we interpret these narratives through the lenses of anthropological theory. In particular, I will interpret these narratives as ethical problematizations that rely on, and work as, a "local" materialist political economy of affect. I want to highlight that, in doing so, I do not attribute a particular sort of agency to Russian people, nor do I claim that they are some sort of "organic intellectuals." Nevertheless, I want to show how, because of vernacular Marxism effects, this "local" political economy of affect is both the most plausible and uncomfortably recursive interpretation vis-a-vis "social-anthropological" theories of affect, the latter being also somewhat materialist, quite sociocentric (or at least intersubjective), and highly political.

\section{FROM DOGMA TO COMMON SENSE}

The scholarly consensus seems to be that Soviet ideological machinery was pervasive, but not particularly persuasive or sophisticated. Soviet ideology was poorly suited to making common sense for people because of the deep gap between ideology and reality, especially as that reality grew progressively consumerist and lifestyle-oriented in the "late" socialist era. The material means by which its ideas and symbols had been put in circulation were also scarce and unimpressive compared to the level of technology available in the world at the time, especially in the ideological centers of the USSR's political rival, such as Hollywood. This, in turn, raises the question of why it was as effective as it was and so long-lived? How did it work?

There are two types of answers, relating to violence, and to language. The former, which I will not dwell on here, is about the disenfranchised, resigned, apathetic populations who were brainwashed through political violence. Answers of the latter type fall within what I will herewith call "linguistic" 
models. The first of these, exemplified and pioneered by Steven Kotkin (1997), portrays Soviet citizens as historically interested in the socialist project, and therefore willing to learn, and use in their everyday lives, the powerful cluster of Marxist-Leninist symbols, concepts, value hierarchies, and forms of speech, for which Kotkin famously coined the term "Bolshevik-speak." This model seems to suggest that this totalitarian, formulaic "Bolshevik-speak" somehow transferred largely unchanged from manifestos to minds. Alexey Yurchak (2005) offered an alternative approach. In his widely followed school of thought, ideological doctrines circulate as performative social orders, as truth-claims that are measured less on the basis of their veracity or falsehood than their effects on life as it is lived. This view canceled the previously unquestioned division between what were seen as the "official" (ideological) and "unofficial" (ordinary) worlds, or words. These "worlds," Yurchak asserts, were separated socially and spatially, and yet they depended on each other for their mutual existence. Because of that, for example, Beatlemania could have been, and was, constructed as "outside" of official ideology; on the other hand, one could have found, and did find, commonalities in the content of the socialist and hippy-esque ideals. Yurchak therefore resolved the question of the "paradox" of in/efficiency of Soviet ideology largely from a formalist perspective.

Some ethnographic studies, however, have claimed that the weakness of ideology does not need to be explained or justified at all. It did not impede but stimulated interpretive effort, and therefore was not detrimental but advantageous for the process of sense-making. Sonja Luehrmann (2011) provides an insight by looking at the work of rank-and-file workers in Russian ideological institutions. They received abstract, schematic, or dogmatic guidelines regarding topics to be discussed with their audiences and the conclusions to be drawn. But it was their task to fill, and to explain, these rather empty (or, perhaps, "performative") schemas using real life situations, people, stories, aphorisms, and jokes. In the words of Michel Foucault, propagandists were given discursive frames and instructed to show how "scientific" medicine is better than traditional healing by comparing science and religion, or to prove that a happy individual is always aligned with the collective by comparing collective and individual power. Their task was to show how and why this was the case and to make their evidence relatable to the lives of their listeners.

Luehrmann's work shows how the schism between ideology and life could have been accepted by people not as a reason to be "cynical," "ironic," or otherwise distanced, but instead as a challenge of creative interpretation and artistic execution. It also prompts an important and scarcely researched question: what were the ideological means outside of, or on the border of, what we usually see as mechanisms of ideology? One that requires our special attention, in my opinion, is the work that ideology does in the largely centralized curricula of mandatory secondary school. For instance, the lengthy studies of (mostly 
Russian) literature within this institution have never been researched ethnographically. I can employ auto-ethnography to explicate what I mean. My mother, a secondary school teacher of literature of roughly forty years' experience between 1960 and 1998, often asked me to help her with her work. In my own schooling years (1982-1992), I helped by sorting out and taking notes from what can arguably be seen as "the tools of propaganda"- - specialized journals and the "methods books." Though this was the time of perestroika, she was still expected to explain Russian (and increasingly, as the country opened up to global influence, foreign) literary works in the "correct" - and Russian-Marxist -ways.

I can attest, however, that, not unlike materials received by Luehrmann's propagandists, these left a lot of leeway for an enthusiastic teacher in terms of explaining and relating the topics to the public. For instance, my mother was given lists of "eternal" (supposedly universally human) "questions" that emerged in the biographies, convictions, and circumstances of literary characters, to be discussed in class. But these were never sufficiently detailed or engaging to organize a class discussion around them. (Dialogic education in the form of questions and answers was in line with Marxist dialectics and "activity"-orientation, and therefore encouraged.) Like propagandists, teachers had to decide how to fill the gap between ideology, literature, and the lives and interests of their students. On the other hand, and unlike propagandists, the teachers had to work with immensely rich and nuanced literary texts that often aligned uneasily with, or could not be exhausted by, the ideological schematics. While many teachers may have read Tolstoy and Dostoyevsky "ritualistically," in the way a bad rabbi would read a Tora, good teachers, like good propagandists, were numerous in the USSR. They also filled gaps in a material sense; I spent many hours drawing stengazetas ${ }^{3}$ on Pushkin or Mandelstam. ${ }^{4}$

The best way to particularize this work, I argue, is through a model of hegemony. A more general anthropological model of power production and reproduction, it does not draw an indefensible borderline between "official" and "unofficial" worlds, or ideology and common sense. Instead it asks, like Luehrmann did, how exactly ideology is received and interpreted to eventually become common sense (and the latter can be, as I will show, intensely antiideological). Drawn from the works of Antonio Gramsci, the concept of hegemony became popular in anthropology as an alternative to "culture" and "ideology." Hegemony, argued Raymond Williams (2015 [1979]), goes beyond culture in the necessary recognition of dominance and subordination, 2002 .

3 On the origins of the genre of stengazeta (usually, a self-made wall-newspaper), see Kelly

4 Mandelstam was an enormously talented and not at all ideologically correct poet executed in the Soviet Gulag in 1938.

${ }^{5}$ For a history of anthropology's engagement with Gramsci, see Crehan 2002. 
and it goes beyond ideology by encompassing not only ideas and beliefs, but the whole lived social process organized, in practice, by specific and dominant meanings and values. While hegemony is attentive to the content of official or "ideological" meanings, their conceptual utility, and the details of their development, it also assumes that there is practical activity outside of ideological institutions that is aimed at utilizing dominant notions to make sense of lives, often subsuming the strange and the incongruous under the familiar. Hegemony, therefore, can be useful in explaining why there has very often been no irony or distance separating the ways people use Marxist concepts in their daily lives, how these concepts can be effective even when contradictory or conceptually underdeveloped, and how Marxian ideas could, and in fact did, outlive Marxian ideology.

My first point, therefore, is that we should examine Russian Marxism as a hegemonic process. This optics does not indicate a particular form of power, but rather a model of any system of power production and reproduction, which can nonetheless be particularized to encompass local cultural and historical specifics. In line with this, I assert that we need to analyze Marxism as a "vernacular." Marxism did not just "trickle down" to "the masses"; transformed through propaganda and education, it was used as an instrument and practice to explain life, as in the Soviet slogan, "Marxism is not a dogma but a guide to action." "Vernacular" Marxism is therefore a social theory living an everyday life, through the process of interpretation that is inherent in the hegemony model of existence.

The following situation demonstrates how vernacular Marxism still appears conversationally, both conceptually and as language. One day,

\footnotetext{
${ }^{6}$ As to why I chose to use "vernacular," the term comes from linguistics to define variants of language that are derived from its "canonical" or textually oriented "literary" versions, and that differ mainly because they have been modified to fit ordinary lives and daily needs. A close, alternative term would be "ordinary" Marxism, but the concept of "ordinary Marxism" distorts because, as an ontology, Marxism is extraordinary in being utopian, extremist, and transformative. Moreover, influential work by Veena Das (2006) has linked "ordinary," at least for me, with the silent and the anti-representationalist aspects of the everyday. Because the materials I present here are mostly narrative and symbolic, I favored "vernacular." On the linguistic side, however, I need to distance "vernacular" from the structuralist - one could say, totalitarian-Saussurian scheme of the difference between "langue" and "speech," in which ideology governs and structures quotidian meanings in the same ways the "langue," or language, structures its particular instances, or "speech." From this perspective, another good word to describe vernacular Marxism would be "metis," a concept elaborated by James Scott (1998), and meaning practical skills or intelligence applied according to situation or circumstance, or in response to pressure or demand, and as opposed to following rules or dogmas. General metis subordination to dominant social structures is undeniable, but like metis, vernacular Marxism may implicitly and explicitly resist the canon as problematic. See also Ssorin-Chaikov's usage of "vernacular" in relation to Marxism (2017).

“'Our theory is not a dogma but a guide to action,'-Marx and Engels always said." This is Lenin's reminiscence of Engels' 1886 letter to Zorge (1972: 323-34).
} 
having a drink at the home of Svetlana ${ }^{8}$ (an electrician, born in 1974) with another mutual friend, Stepan (a policeman, born in 1975), I happened to mention "Soviet ideology." Putting "Soviet" and "ideology" together struck a nerve. In the Soviet Union, Svetlana asserted, movies and books were "not ideological" because "the authors never wanted to 'say something'! They merely, simply, stated the facts!" Stepan added:

Look, I really enjoyed the film. ${ }^{9}$ And then those idiots at work told me it is "Soviet ideology." I told them-listen to me, you morons! I will bring the book [from which the film was adapted ${ }^{10}$ ] to prove it to you.... Simonov [the book's author] described in ruthless detail how someone is killed by the protagonist. He kills a soldier who stirs panic, and he kills him accidentally. When the civilians are killed, it happens because there is chaos and panic about, and they are suspected of being spies. And then a crowd of running Red Army soldiers is shot and killed and the detachment is disarmed, and then squashed to death indiscriminately by tanks. You want to say it is "ideology"? It is just the harsh and merciless realities of war!

So, I asked, 'If the writer describes a 'merciless reality,' there can be no ideology in it?" Svetlana replied, "No, there is no ideology in it! It is not a flag or a banner in a parade; it is left to your own perception. You choose how to interpret this."

\section{ONTOLOGY OF SEMIOTICS}

The majority of my informants belong to what I call "the teens of perestroika" (Kruglova n.d.), or indeed the "last" Soviet generation (see Yurchak's broader definition of the "last Soviet generation" in his 2005 eponymous book). They are my friends and peers, and most were born in the mid-1970s. Their income levels were the median for Perm in the time of my fieldwork (Kruglova 2016). With regard to the education, however, one must note that while 24 percent of Russians are credited with some university education, this figure stands at 30-34 percent among those born in the 1970s (Bessudnov 2012). It may be more common for people of this age to be nostalgic for the Soviet past, and they do not deny sharing the sentiment. They lived through drastic social changes as they were maturing and they were often traumatized by bumpy starts to families and careers in the turbulent 1990s. This is contrasted with the timelessness, secure certainty, and serenity of their late socialist childhoods. ${ }^{11}$

But their childhoods were also "Soviet" in the sense that they were by no means insulated from the indoctrinations delivered at schools and the quotidian

${ }^{8}$ I have taken a number of measures to preserve anonymity, among them using pseudonyms. Because all sort of registries and databases in Russia are filed by people's year of birth, I have randomly adjusted those within the range from one to three years, still preserving the important generational context. Some people in the study knew each other, but as many or more did not.

9 Zhivye i mertviye, 1964.

10 Zhivye i mertviye was based on Konstantin Simonov's book of the same name.

11 I give more of their biographical details in Kruglova n.d. For an overview of late socialism as the "golden stagnation" of USSR historiography, see, for instance, Shevchenko 2009. 
public communication that assumed a degree of mastery in thinking with, and speaking with, a number of "pseudo-sociological" (Magun 2014: 206) conceptual and discursive elements (see also Lemon 2004). Significant among these "objectified social imaginaries" (Kalinin 2012) was obschestvo, "society," an imagined collective of Soviet people - the builders of communism. Another famous one is a "collective" (see Kharkhordin 1999), which has much to do with criticized, and yet not entirely abandoned, sociological and anthropological divisions between gemeinschaft and gesellschaft (community and society). This is not surprising, since Soviet social engineering was very concerned with organizing the ways in which small groups could be brought together to constitute the society. Other key elements were "the question of women" (zhenskii vopros), which encompassed Soviet understandings of feminism and gender relations (although, famously, never sexuality); the condemned "race" (rasa); the endorsed "ethnicity" (narodnost'); and the morally ambiguous "class" (klass; see Fitzpatrick 1993). Through education and the media, the notions of "power" (vlast'; specifically "Soviet power"), "history," and "progress" became equally habitual, but not at all, or not necessarily, meaningless or "ironic." "Culture" was learned through the guidelines for cultural production in the "Houses of Culture" (Grant 1995; Donahoe and Habeck 2011), and via the manuals on how to be "cultured" (Kelly 2001). "Morality" was explained through school curricula, activities, and special brochures like the "Moral Codex of Communism Builders" (Kharkhordin 1999: 231-51). "Language" was a focus because of the incessant touting of the sublime qualities of the Russian language. People differentiated between "theory" and "practice" and between "work" and "labor," and they valued "activity" as a moral way of life.

The paths for analysis of these meanings and social imaginaries were numbered and authoritatively decreed (see Lemon 2004; 2008). Since 1991, the usage of such words has been understandably on the decline because of their association with the once compromised and now controversial Soviet symbolic order. And yet, like "ideology," they were a part of daily life and its problems, and not only as "just saying" them - a riff or an irony. They became schemas, explanations that, however habitual, connected cultural, social, and historical contexts to the ways of practical moral reasoning. The very concept of "ideology" continues to provide cognitive and affective tools for the objectification of one's own and others' social and historical conditions, for thinking about social and cultural aspects of life as if they were separate from life.

This is why the "ideology" explanation could be raised, as Stepan recounted, without my "anthropological" presence or unwitting provocations from me. This is also why we should study these ideas not merely as "slogans" but as concepts that cannot be fully comprehended if we fail to understand their connections to local variants of Marxism. My interlocutors were indeed concerned with the power of ideology as a sociological 
problem, because their education conditioned it, since the pernicious power of ideology was a central suspicion for Marx. As I see it, Svetlana and Stepan believed that ideology, to be ideology, has to be a "message" and a "banner," a clearly formulated statement of intent — what John Austin calls "an illocutionary act." Existentialist portrayals of various uncertainties - accidents and panic and chaos - they find explicitly not illocutionary, since intentionality, or interpellation toward the spectators, is absent. In the absence of a clear political statement, or when social contexts are not declared or at least implied ("absented," as Nafus writes in her 2006 article), the subjects of ideology are free from its power.

We cannot say that this "ideology of ideology" is a "mythology" coming from the specificity of local contexts. It is a self-aware epistemological-and existential-opinion. Conversation about "ideology" is not dissimilar in its form, procedures, and concerns from what anthropologists and other scholars often identify as theory. What theory, then, can be "applied" to such a material, and how? Can this "local" ideology of ideology—a telling tautology—perhaps be theorized as a "semiotic ideology"? Webb Keane (2007) sources his deservedly influential inspirations for the concept of "semiotic ideology" in Charles Peirce's semiotics and Michael Silverstein's "linguistic ideology." "Linguistic ideology" is the hierarchies and values attached to different aspects and usages of language (its capacity for clarity, sincerity, profanity, etc.). Peirce, on the other hand, famously expanded and reformulated Ferdinand De Saussure's classic semiology by describing various types of relationship between material objects and their "names" (signs, symbols, indices, etc.). Keane, one could surmise, attempted a spirit-of-our-time materialist move by expanding Silverstein through Peirce, and therefore moving beyond meaning to directly include matter into equations. When "lay" people theorize the very relationship between things and language, or how things signify, extrapolates Keane, they theorize in terms of semiotic ideology, not linguistic ideology. Semiotic ideology, therefore, is also necessarily a description of the hierarchical types of agency and its distribution in the things of world (ibid.: 1-6). Christian semiotic ideology, for instance, is concerned with the status of the Holy Bible, which some see as divinely agentic, and yet the materiality of the Book(s) and their mechanically reproduced qualia make them ethically and ontologically ambiguous (Engelke 2007).

Marxism is certainly a semiotic ideology, and yet we cannot talk about "local semiotic ideology" without noticing how locals cringe at the word "ideology." But even more curious problems arise if we keep in mind that Russian Marxism is, explicitly, an atheistic materialist ontology (Magun 2014). In "semiotic ideology," a relationship between a thing and its sign or, as Keane extrapolates, between thingness and agency, assumes a possibility of separation (albeit mostly theoretical, "in the mind"; see Lambek 1998) between thingness and agency. In other words, the very idea of semiotics is still premised on a 
possibility of both completely immaterial spirit and unspiritual matter, with the degrees of spirituality/meaning/agency infusions in between.

For Marxism, therefore, semiotics is problematic because it still affords (in theory) a purely ideal, or spiritual, existence. In other words, semiotics in itself is a semiotic ideology, and from the Marxian point of view, an unsuccessful attempt to overcome traditional European idealism. But curiously and contradictorily, the impossibility of immaterial ideas in Marxism (Leninism) does not cancel the acknowledgment of their practical effectiveness. Ideas are utterly world-making, and transformative. All this, in part, is at the root of why "agency" in the USSR has been so famously contradictory. Apart from purely political reasons of having a population that is both enthusiastic and indoctrinated (Yurchak 2005), my two cents are that "ideology" appears to be the Marxian equivalent of the Christian problem of evil, or the Devilacknowledged as ontologically impossible if God is good, yet obviously present as the influential not-good. This makes the problem not only epistemological but also ethical. The problem for anthropologists, however, is that in Russia we run into a "semiotic ideology" that already contains, in itself, a critique of both semiotics and ideology. In the vignette above, the "ideology of ideology" is a telling tautology that belies a type of recursivity, a peculiar selfreferentiality, which is bound to happen, and indeed does happen, but most of the time goes unnoticed when "social theories" are "applied" to Russian "material" without critical self-awareness.

\section{AFFECT: THE PHYSICS OF THE SOCIAL}

Many Marxian notions became our own "anthropological" commonsense vernacular. Just to name a few: production (of both things and relations), exchange, capital and dispossession, commodification, alienation, and political economy. This is especially the case with political economy, a developing product of a variety of intellectual and political movements, some Marxist and some not. Ethnographies of political economies move beyond an explicit concern with modes of production and emphasize class, culture, and politics, placing their subjects within the formation of a world economy and the development of capitalism. It is due to interest in political economy that anthropologists took to researching the circumstances associated with getting a living, and the structures of power that shape and constrain activity (the "structure and agency" problem; see Roseberry 1988).

"Affective" enchantments emerged in anthropological theory in the beginning of 2000s. ${ }^{12}$ Affects, the consensus seems to be, are not (just) emotions but "intensities" and "significances" (Stewart 2007) that are intersubjective,

12 Key readings on my list of affect theory would include Massumi 2002; Mazzarella 2009; Stewart 2007; Gregg and Seigworth 2010; Berlant 2007a; and Sedgwick, Kosofsky, and Frank 2003. 
historical, and embodied, but impersonal (Mazarella 2009: 11). ${ }^{13}$ Special attention is paid to the embodied effects of affects, and to people's real and imagined relationship with things (that is, to semiotic ideologies). Political economy is also a crucial part to affect studies, a way to explicate how affects are structured by their larger contexts such as capitalism and neoliberalism.

The problem is that in the world of my interlocutors political economy is not a matter of analytical optics, but rather the default human condition, where practically any process is social and a type of production. Affect is most valuable, and the ontological primacy of matter presumes that valuable things cannot be disembodied. This embodied nature of affects, as well as their scientistic nature, may be interpreted from their curiously "physical-mechanic" (Kruglova 2016) descriptions. But the materiality of affect is often acknowledged unequivocally. One day I complained to my friend of many years Tatiana (a sales agent, born in 1974) about an unusual aggravation in my usual share of troubles. Over a meal we shared at a supermarket canteen, she said that the reason behind my troubles was simple: I talked to people with little caution. Thoughts and words, she warned, are material'ny, "have material substance," and so they affect objective reality just like any physical matter would:

My sole explanation - someone became envious of you. Maybe even here in Russia, you met someone [who is magically potent]. You never put up any defenses, obschayeshsya [perform obscheniye, communion]; you tell people everything [that is on your mind]. There are people like me who do not care-a person lives abroad, so what? But there are people who would want to do you [i.e., to magically harm you]. You need to go to church to cleanse yourself, even if you are a nonbeliever. By the way, you are a grownup now; you should take care of yourself and get baptized. It is not a big deal. People [born into the antireligious Soviet regime] do it all the time. There are also other ways to cleanse your energies - those you can find on the Internet. Because I do not think that it is your own attitude to life that has changed. If there is such stuff in your aura, in your okruzheniye [environment, and, tellingly, also social circles], that should be fixed. And hurry - you have to resolve it quickly because this depresnyak ["depression" but with an altered suffix, -nyak, this makes it very informal and therefore without a pretense to medical diagnosis] will suck you in. Someone became envious of you, probably due to your money.

Initially, I coded this explanation of "communication metaphysics" as "magic/ religion," a kind of Malinowskian "rationality in context." Tatiana herself identified as a "doer," that is, as a magician, and also a true legacy Orthodox. But later this metaphysics proved to reflect a common view, hardly affiliated with any kind of magic. One of my interlocutors, to my direct inquiry as to

13 The ontological status of affect remains unclear, although the poetic gifts of Laurent Berlant and Kathleen Stewart, two prominent developers of affect theory, have made affect in some senses clearer for their readers than any encyclopedia-style definitions. A radical possibility of affect as a material flow, a sort of material energy, is entertained by Brennan (2004), but anthropologists have not gone that far. On "energies," see Lemon n.d. 
whether such beliefs were magic or science, shrugged it off with a remark that he would not know for sure, but they well may be scientific because "everyone knows that the human body is a battery," and therefore, there could be "some sort of stuff exuding from us into the world." We can equally plausible see in this vignette the influence of a "psychologizing" of Russian society (Lerner 2011), and indeed the self-help industry exploded during perestroika, often through translations of Western techniques into local languages and mindsets.

My point, though, is that everything a Western psychology might offer can easily recline on the couch vernacular Marxism has unfolded for it (unless it is Freudian ${ }^{14}$ ). In this "vulgarly" material Marxian world, affect is of utmost ("moral"? "material"?) value and an exhaustible resource. Affect is vitality and intention produced from within one's self and directed outward, through thoughts, words, and actions, to ever-widening outer circles (Lemon 2008; 2009; Matza 2010; Buck-Morss 2000: 104-15).

Affects are like particles in physics in that they become charged as either pozitiv or negativ. The essences of pozitiv and negativ - upbeat and optimistic, or depressed and gloomy - are applied often and to everything: people, places, emotions, thoughts, and words. Negativ is naturally a bigger concern. People nowadays, in the words of another friend, "became zlyie," angry and begrudged (see Hann 2011, on "moral dispossession"), generally in the new circumstances of consumerist, capitalist Russia, but they grew especially so after the crisis and the concomitant communality of the 1990s were over (Shevchenko 2009). Communication is filled with a threat of affect dispossession-insidious agendas, unpleasant surprises, threats of "brainwashing," or "loading"gruzit', unnecessarily straining one's affective structure with irrelevancies or abstractions - usually as a prank or to show off (Kruglova 2016). Depresnyak, therefore, is both a state of mind (often explicitly seen as contaminated) and an intersubjective influence of material affect. Some people, like psychologists and mages, can influence reality and rob you through words and thoughts.

The separation of discourses is also gendered: women lean toward magical explanations, men toward more manly or "scientific" forms of magic such as "astral karate" or neuro-linguistic programming. The latter's tropes sound much like those of battle magic. Tatiana, a curious case of a feminist, viewed herself as a bit of a battle magician. But people with no special skills, or beliefs, could also harm me, she said, especially if they felt strongly when they talked or even thought of me. I may have become a target of envy because people are gullible, and they have been brainwashed to believe that anyone living abroad is rich. (She hastened to add that such people are seriously deluded, considering that I was childless, poor, and still at university studying "God knows what" while approaching my fortieth birthday.) But there still is a

\footnotetext{
${ }^{14}$ In the USSR, the Freudian story that proposes an existence of an ungovernable un/subconscious in people was officially banned. See Etkind, Rubins, and Rubins 1997.
} 
living ideal of obscheniye, perfect carefree communion/communication among svoi/ours (Yurchak 2005), in which affects/energies are produced and shared freely and are enriched in circulation. Tatiana and I both acknowledged that our conversations with each other were obscheniye.

\section{AFFECT: SOCIOLOGY AND ECONOMICS}

One day Pavel (a security and tech support, born in 1975) and I were sitting on the patio of a local eatery drinking brandy and coffee, respectively, and watching people enjoy a summer evening. A young and pretty girl walked by and I observed her tan and mascara, and the work she put into her appearance. I thought how Lauren Berlant (2007a: 287) might say that this mobilization of articulated sexuality was a performance of "affective avarice," "a demand for a feeling fix" that injects "a sense of normality" and "being intelligible" into our shared "precarious neoliberal condition." Pavel's interpretation of her appearance was similar in that to him it was clearly an expression of an affective political economy:

Look at this poor girl- when we sat down in this café, she walked this way, and now she is walking back. In her short skirt, so lonely. Her head was so low-she is clearly bored. No living creature wants to chat her up. Guys are lazy! I walked the street the other day and saw a girl - beautiful, so tanned, so slender. She was dressed literally in lingerie, in something transparent and pink. I saw two guys walking after her, drinking beer, at a distance. I laughed and asked them, "Are you trailing the girl?" They smirked, "Yes, we are!" But they did not make any attempt to chat her up. They just enjoyed the show, as if in a strip bar-nakhalyavu! [giving nothing in exchange].

Whenever I talked about peoples' relationships at work, the intimacies of kinship and friendship, or intensities of love, they indicated that cultivating desire is a necessary form of work that preserves one spiritually, and this work is taxing. They said desire is a product of this work that can, and should be, exchanged in an economy, in order for production to continue. The girl's performance of sexuality was work of this sort, a cost, and a product that should have been, according to the imagined contract, paid for with equally desirous attention. By exchanging this knowledge in routine conversation with me, Pavel was also performing moral work, because it was in itself an exchange of pozitiv energy. He disapproved of what he saw as the anemic sexual dispositions of the local men who did not pursue the girl. "The guys" were lazy - they lacked abundant productive capacity and so took what they could take for free ("like going to a strip bar for free"), and then left. For Pavel, desire is therefore an economy, as Berlant suggests, but if it is virtuous, it is never "affective avarice." In vernacular Marxism, desire is a generative rather than acquisitive process, ${ }^{15}$ and therefore indeed more of an affect than a "desire"-it is internal sociocentric production projected

${ }^{15}$ See Deleuze and Guattari 1983 for a critique of the acquisitive, "Lacanian" model of desire. 
outward, given to others, sometimes violently (Lemon 2008), rather than something entering from outside, like filling a void.

A moral subject therefore produces affect by being industrious in its production and also by following the technologies of its production. Only certain types and circumstances of exchange, contact, or conflict (dialectical tension; see Lemon 2008) with others produce the "something," not entirely tangible, which works behind - or rather through — "words" and "communication." Virtue therefore requires knowledge, readily shared, of various "sociological" conditions of gender, generation, ethnicity, class, and institutions that facilitate or hinder the production. Unfairly, it seemed to Pavel, the girl's work and her product were cheap these days, or "the guys" had insufficient affective currency to reciprocate with equally articulate gestures. He recognized the "social fact" of the imbalanced "energies" in the gender market, reiterating, it seems, the long-standing discourse about the emasculation of Russian men (Zdravomyslova and Temkina 2002; Utrata 2015). But unfairness in affective gender exchanges in Russia was common fact, common knowledge, and a common topic of conversation. Elena (who works in tourism, born in 1974) said bitterly that she had almost abandoned any hopes of marrying. Nonetheless, she learned to play poker and went to predominantly male poker parties "to absorb some male energy." She did not specify whether she gave any of her own feminine enthusiasm in return, and I assumed that a poker party was a place where, like the street promenades, some gendered energy could be gotten for free.

Not surprisingly, then, some men confided in me about their spousal infidelities and framed them as affective therapeutic and moral charity, as generosity with their male energies. Stepan, who discussed ideology with Svetlana and I, took pride in his athletic physique and gift of gab. He told me with a mixture of pride and irony how he was "picked up" (snyala, a word that also applies to prostitution) by a very wealthy woman: "She asked me, 'Do you drink cognac?' I went with her to her apartment." I interjected, "For a "cup of tea'?" "Yes!" he responded, laughing, "I had never seen such a palace before." The affair lasted for a while. His interpretation of it was that he saved a nearly "lost" woman from a crisis of affective production. His work was so important because it is hard to begin desiring again after a prolonged break. Like a factory furnace that stands cold for too long, the man or woman risks never being able to get hot again. One who does not strive to exchange one's desire, social conditions notwithstanding, risks an affective and therefore spiritual bankruptcy, reaching a point of no return - a prospect that haunts local moral imaginations. Stepan made it possible for his mistress to maintain the good work, the good production, until she found a suitable bachelor to marry.

This is an example of how affective charge can work, to some extent, to mitigate the widening inequities in the Russian class landscape. The exchange took place across recognized class lines, to mutual benefit, and Stepan's mistress was wise enough to appreciate it despite her higher (bourgeois, 
burzhui) status. He still proudly receives her respectful congratulations on the "Defender of the Fatherland Day"- a celebration of "men in general" since, theoretically, all men undergo one year of mandatory military service. It serves very conspicuously as a counterbalance to International Women's Day.

Pavel was more modest than Stepan about the "net value" of his contributions to his mistresses. He was equally generous in his energies, but he acknowledged the unfairness of the exchange in a market where his masculine but supportive sentimentality was in high demand. "In a land with so much negativ" (material energy, or "affect," of burnout and grudge) and "so many single women," as Pavel said, his energy was much sought after. "Every second woman here is a single mom, or, you know, semi-divorced," he said, "and all that they want is just some personal attention ... and a toy to play with." It was not clear if by "toy" he referred to himself, or to the common custom of expressing sentiment not with voluble words (or one would say, ideological statements), but rather with simple yet material tokens, especially flowers and stuffed toys. So Pavel was offered, and took, more than just casual pleasure. Many of his life opportunities-loans in time of need, contractual favors, great advice - came from women who rewarded him for his affective articulations. He charted out his relationships with them as multi-sided equations (see also "hermeneutic algebra" in Lemon 2008): good sex he found with every woman, but one was a particularly good listener to his troubles, another cooked, and yet another was "a very, very good person, smart and kind," in addition to being "rich and well connected."

In time, the equanimity with which Pavel accounted for the transvaluation between the bodily, interpersonal, social, financial, and ethical qualities of these relationships seemed to dismiss "love" as some sort of ideology and therefore a form of dishonesty. But this frankness, some would say cynicism, acquires depth if read with/through/as vernacular Marxism. For a vernacular Marxist, I argue, the European idea of "love" as a "natural" "force that conquers all," and hence is cost-free, effortless, mindless, and apolitical, remains not just a romantic but an exotic im/possibility. ${ }^{16}$ In other words, the moral intensity of his transvaluation revolved around the very conflict between the possibilities of affects being natural (essential and therefore cost-free, naturally produced within subjectivity) or social (constructed in the way of being a work of the soul, which is also highly susceptible to social influence). Affect always reflects, and expresses, the infamous contradiction of Marxism, and with it also the vernacular-Marxist morality, which sees energy as an alienable value

\footnotetext{
${ }^{16}$ A common observation made by affect theory polemicists is that all types of labor engage affect, but in capitalist political economies the affective side of labor is assumed to have value but to come at no cost. ("Smiling does not cost you anything.") For Russian vernacular Marxists, however, genuine smiling costs, and fake smiling is a sure road to perdition, as explained below in the stories of "two dachas."
} 
because it is a product and an exchange, but also a moral, inalienable virtue because it cannot exist without moral work by the self (see Lambek 2008).

Tatiana espoused the same generative (or productivist, or realist?) view of desire. Money was hard to come by, but at least its sources were known, and she worked hard to mine them. In the 1990s, she left behind her "useless" university degree in philology to build a career in wholesaling consumer goods, putting her social skills and personal charm to great use and general success. "Male energy" was a different matter. She claimed that she declared in no uncertain terms to her prospective beaus that she sought only what can be seen as the practical, use-value of casual sex, but she would tolerate no excuses for sex itself. And yet the majority of men simply failed to satisfy her. To find those who behaved with bold and manly articulateness, she had to suffer through many unpleasant dates: "Yes, he said that he wanted it. But this was just so fucked up! I cannot be around such men. He talked and talked and talked. It was okay when he talked to compliment me, but when he started this-I don't know-I said, 'Yes, I get what you mean already. I got you.' That was all, enough, you can move on! On! I could not stand it!" Tatiana's ideas of manliness were inseparable from articulating desire through a forceful bodily action, which, in the same economy, was "rewarded": "In truth, I want a man who can smash his fist on the table so that I will shake a little in fear! ... Yes, I keep up an appearance of being unavailable. This is because I like men who take risks. Those who take the risk, get rewarded!" The traditional and sanctified "rituals of talk" (Ries 1997) may be about performance, but they obviously were not doing enough for Tatiana. Her suitor articulated his desire with an outpouring of words, but in the end she could find no substance, in the sense of bodily, physical, material, or use-value. She found no "praktika" or "aktivnost" (activity).

To conclude this section, I ask: can we, following theories of affective engagement with the theories of the world's neoliberal condition, interpret the "exchange of energy" on the gendered affective markets of Perm as "neoliberalism"? On one hand, the economism and emotionalism of this exchange, the imperative to sustain one's productivity, could indeed be seen as a neoliberal triumph. Even the charitable concerns in this exchange (as in Stepan's story, above) may fall in line with the concept of the global neoliberal who is increasingly a "moral neoliberal" (Muehlebach 2012). But Marxism, if anything, is a powerful critique of capitalism, and therefore necessarily a critique of neoliberalism. When routine conversations and judgments among "laymen" are not illustrations or inspirations for theory, but instead reflections on and indeed contestations of this very theory, then analysis of theoretical frames and their silences requires a special self-awareness. 


\section{AUTHENTICITY OF AFFECT: THE TALE OF TWO DACHAS}

Pavel seemed appreciative of his family's economic success. His in-laws owned a dacha, a summerhouse with a vegetable plot attached for some smallscale husbandry and agriculture. ${ }^{17}$ His in-laws did not only well but good: like most dachniks, they engaged in the production of use-value goods, catering to basic human needs of sustenance and consuming the produce rather than selling it as commodities. ${ }^{18}$ Although the words rabota (work) and trud (labor) are often used interchangeably, there is a conceptual difference along the lines of Hanna Arendt's distinction in Vita Activa between different activities and their costs to humans. Activities that reflect the cultivated and civilizational, and therefore less natural aspects of human existence incur injuries from which more natural activities are free. Gardening and other dacha activities, like house chores, are seen as more labor than work, and therefore moral and restorative rather than energy-costly. The dacha is an escape from work to labor, from city to countryside, from civilization and modernity to archaic, peasant, status-less commune, away from the hierarchies, wages, clocks, and other demands of the urban working week. ${ }^{19}$ Pavel called it "our" dacha, thus identifying with its hustle and bustle and abundance of use-value goodness. "There at our dacha, it is nothing short of a khozyaistvo [literally "a homestead"; a self-sustaining economic unit]. We have a hundred rabbits, maybe forty egg-bearing hens. Three cockerels. Rams. Sheep - one should lamb soon. Then the geese, maybe twenty of those. Three dogs, two cats. A whole khozyaistvo!"

And yet, the situation at the dacha was deeply troubled. I heard the turn of the tale when I dropped in for tea at the apartment that Pavel still shared with his wife. She was a bit of a hoarder, and the dacha was the main excuse for the hoarding to continue. Every scrap of leftovers - milk, bread, fruit, meat, a battery of opened jars with a smudge of jam or a single pickle on the bottom - all were stored outside or in two huge overfilled refrigerators in the heat of summer, where they were saved "for the dacha" to feed the animals. Scraps of building materials and heaps of old clothes and empty plastic bags lie around in case they might be handy, one day, at the dacha. ${ }^{20}$ Pavel, seeing my (forcedly nonjudgmental) astonishment at the flat's hoard, got

\footnotetext{
17 Like urban apartments, most dachas were deeded to people for free in the distributive economics of Soviet days and came into legal private possession in the 1990s. They now constitute a solid part of people's equity, of which cash flows, savings, and other monetary assets often continue to be less significant components.

18 See Kruglova 2013, on the connection between affective economies and the (Marxian) concept of "simplicity."

19 Melissa Caldwell (2010) describes beautifully these "Dacha idylls."

20 See how the quite similar "frugality" is interpreted in Ries 2009, mostly as an ontology stemming from the trauma of the infamously depressive history of Russian/Soviet food and other material deprivations.
} 
excited and switched into horror story mode. The dacha was a problem. Pavel's wife obeyed her mother's orders and worked through the day and into the night, while her family scorned Pavel for "laziness." They, too, toiled from dawn to dusk, churning out agricultural produce. All this effort to earn money was in addition to his wife's full-time job, her and her mother's small but lucrative business making fur accessories (a commercial, and therefore morally more reprehensible enterprise), her father's pension, and Pavel's own salary. Yet they disapproved of spending on gadgets, cosmetics, clothes, vacations, or other goods that are the small pleasures of nascent Russian middle-class consumption (Patico 2005; 2008), things that are the vectors that help the outward articulation of desire, like the tan, mascara, and pink lingerie of girls strolling the streets of Perm. Instead, Pavel's in-laws collected foodstuffs, poultry, livestock, timber, and sugar, all "simple," morally good materials of clear use-value, albeit in quantities too great be consumed. He noted that they risked cholesterol crisis and heart failure from trying to eat all the eggs laid by the hens.

Pavel believed his marriage by then to be entirely loveless. He was sad at the prospect of divorce, which his wife was likely to initiate, but nothing could be done-she "did not want anything anymore." She produced no affect (at least not toward Pavel). This stoppage of outbound flow, the focus of his narrative, worked in seamless tandem with the stoppage in the outbound, generative material flow, the motion from inside to outside that took the forms of gifting, spending, giving away, or even throwing away. Instead, all sorts of piling, muddying, and stuffing up took place: in houses, in bodies, in souls, and in the palpable verbal inarticulation that inevitably and negatively charged his marital life (I witnessed the awkwardness on several occasions). Despite all the signs of virtue - the use-value, the labor, the nature - the in-laws misrecognized the dacha by failing to see that affect was not produced there. They were blind to their own spiritual death. Perhaps the most painful part of it all was that no one "had the time," as Pavel said with portent bitterness, to care for an elderly member of the family who suffered from dementia.

A dacha was the symbolic center of tension for Yurii (a journalist, born in 1974), though in a curious and telling reversal from Pavel's situation. Yurii's in-laws did not work or labor at their dacha, and indeed they pointedly abstained from any activities lest they turn into any demanding mobilization of work. The point of the dacha for them was "restful" tea drinking, eating, and sleeping. The dacha, bemoaned Yurii, threatened him on the existential level: "It turned into an exile for me. Because they always push us to sleep-and to gobble, gobble, gobble — all the time! And drink tea, they call it chaovnichat' [a pointedly rustic word for a tea-drinking ritual] — how I hate this word! After tea, they want to 'flop on the side,' meaning to sleep. It was horrible. I mean truly, I was frightened when I realized that I was losing it." 
In other stories, however, Yurii acknowledged that such "restful" technologies of self were virtuous, and told me about his own pointedly "unproductive" pleasures. He went for leisurely strolls with his little son in a buggy. There were sessions of beer drinking and watching television that he himself organized, for himself, on a whim, especially on business trips away from home - he made hotels into improvised dachas. Sitting on a park bench on a good day and watching people playing cards or exercising was one of his favorite pastimes. So what was the difference between the "moral" laziness of beer drinking in a hotel and the "immoral," "spiritually deadly" tea drinking at the dacha? Comparing it with Pavel's story, why can both working and resting at the dacha be so abhorrent?

In Marxist-Leninist moral education both production and rest are explicitly articulated as a part of a personal moral economy, and a social contract. While Yurii's in-laws' preoccupations at the dacha are a familiar trope, a key part of the social contract in the socialist welfare state was the human/laborer's right to rest, to concentrate on restful, inconsequential activities, understood as pointedly antithetical to work, in order to sustain production (Kruglova 2013). Once again, I quote Lauren Berlant (2007b), who suggested that we see eating, sleeping, and other such activities that are understood as "having no consequences for one's subjectivity" as "lateral agency," as a form of political agency. This perspective would need no explanation to anyone in Russia except perhaps people under thirty; as I was told, "You don't have to be an anthropologist to understand this." But "drinking tea" can also be turned around and condemned as being "inactive"- that is, unproductive, as taking the right to rest too far or as fetishizing restoration for the sake of restoration and not for the sake of returning to productive activities. The story's point was that the goodness of simple, use-value foods, or rest, or labor, do not, in themselves, guarantee affective productivity. Virtue lies in a person's capacity to recognize affect and to ward off situations in which the production of affect is falsified, intentionally or not, rather than delivered in earnest. ${ }^{21}$

These subtleties and difficulties in recognizing "good desire" may be associated specifically with the intelligentsia ethos (and its own fetish, Russian classical literature ${ }^{22}$ ), but I have found that both its social base and its uses are much wider. Anyone can point out authenticity or inauthenticity of affect, as a means of gaining symbolic capital, as a moral practice, or as a way to frame one's social milieu. One might say that the intelligentsia merely have more articulate means for talking about it. My point, however, is that frustration

${ }^{21}$ See Slavoj Žižek's (1989) understanding of such misrecognitions, in the line of Marxian theories of fetishism.

${ }^{22}$ The plot of the Yurii and Pavel stories, and their anti-fetishistic charge, are entirely translatable into the moralities of Chekhov's story "Gooseberries," which is a staple of every secondary school curriculum. 
with "doing nothing, only drinking tea" was hardly a phenomenon that needed to be described or discovered by an anthropologist or other professional observer, who might later theorize these moments as indicators of the neoliberal condition. ${ }^{23}$ Russian everyday morality was already organized around the contradictions between this obligation or right to produce and the obligation or right to rest. To mobilize and demobilize: these are themselves already a critique of the neoliberal condition that people voice without filters. What, then, does this mean for anthropologists who assume that they hold a monopoly on reflexivity?

\section{WORK AND LABOR}

Another vernacular Marxist ideology, or social theory, describes the relations between self, work, rest, and labor. ${ }^{24}$ As I explained earlier, in Russia mindless and responsibility-less bodily labor became a sort of ideal, a schema that sedimented into values over the decades. Although such labor is sometimes backbreaking (and growing vegetables at one's dacha is notorious for ruining one's back), it is virtuous because it gives one a respite from any (always pernicious) "ideology," and, ironically, from the default ideology, the Marxian politicization and sociologization of human lives. The bodily focus of concentration on work also allows one to be impervious to the possible negativ of one's own thoughts that come in moments of lonesome idleness. In other words, such labor is one technology of virtue that utilizes unthinking bodily ecstasy instead of the usual mindful, moral vigilance. For this reason, the Soviet slogan "The right to labor" might sound Orwellian, but expresses the labourer's political interest when juxtaposed with activities that are definitely "work." The post-Soviet landscape, for instance, was characterized by the emergence of many previously unfamiliar types of wage-work, especially in services that assumed waiting on customers, literally, in pernicious, mindful, vigilant idleness. Most of my informants recognized this as truly soul-numbing work, and the connection between the new capitalist order and the proliferation of such work did not go unnoticed (Kruglova n.d.). Gardening, by contrast, is a time-honored labor tradition.

Now, folding sweaters on a shop floor may be viewed as soul-killing in most "Western" countries, just as gardening may be seen as relaxing. To a vernacular Marxist, however, these divisions are not merely subjective experiences but truths that are rooted in material science (that is, Marxian ontology). Some medical practitioners in Russia seem to still follow these prescriptions.

23 Compare with "drinking tea" in several studies about frustrated young people (Jeffrey 2010; Mains 2007; Masquelier 2013; and Sykes n.d.), to whom "drinking tea" is symbolic of their historically structured, endless "waiting" for a job or other signs of social and personal maturation.

${ }^{24}$ On how the same political economy of affect plays out in the public spaces of Perm, see Kruglova 2013. 
Energetic home chores are "laborly" and therapeutic, so when Marina (an industrial chemist, born in 1975) consulted a doctor regarding a bout of anger and depression he recommended she take a pillow to a nearby park and beat the dust out of it. With the advent of vacuum cleaners this is a chore one rarely sees people doing nowadays, but it was a regular household task during Marina's childhood (often performed by men, especially for heavier carpets). Not only did she follow this advice, but she also took her five-year-old son to beat pillows in the park because, "You know, the social atmosphere in kindergartens these days is toxic, and he is also very tense." That physical exercise reduces nervous tension may be common knowledge everywhere, but what would it change if we acknowledged, in this particular case, the connection between common knowledge and Marxian ontology?

CLOSE, TOO CLOSE, NOT CLOSE ENOUGH: THE AWKWARD

REVELATIONS OF VERNACULAR MARXISM

Describing Russia as Marxian is like describing Europe as Christian: it explains everything and nothing. Still, it is hard not to notice that twenty-first-century Russian morality in many ways is unremittingly Marxian. Russian Marxism (-Leninism) is a habitual formula, a habitus, and also a semiotic ideology that centers on, and complicates, separations of activity and mind, or epistemology, ethics, and ontology (in which sense, perhaps, it is the only true form of Marxism there is). My point is that without attention to the ways Marxism informs the "cognitive organization of the world" (Verdery 1996: 4) in Russia, one can comprehend it to about the same degree that one can understand Jain ethics without reference to, or knowledge of, Buddhism and Hinduism. I therefore call for rediscovering Marxism as a vernacular and a hegemony, as a language and a set of schemas that render Marxian concepts as basic technologies of the self, tools for identity construction, and means of differentiating class and bringing moral condition and moral agency into daily life.

In this essay I have made the case that recognition that this lineage of social science thinking is shared by anthropologists and their interlocutors in Russia, and possibly throughout much of the postsocialist world, can go a long way toward better understanding the worlds we study. Most anthropologists, following the discipline's mandate to connect a generalized set of ideas to particular social worlds, might readily agree with this. Finding tensions between "our" and "their" "social theories" has been our way of capturing the new and rethinking the old. ${ }^{25}$ But today there is a particularly poignant

25 In his early work, Michael Taussig showed the beliefs of Columbian miners to be a realization, ritualized rather than narrated, of the fetishistic power of the commodity (1980). Marylyn Strathern (1988) famously observed that Melanesians' views on humanity's social nature are truer to the social science framework than those of people who already believe themselves to be subjects of Western modernity. Humans, she contended, are collectors of social statuses and mutual relations, 
and growing realization that our informants tell each other and themselves stories with plots that resemble those we "anthropologists" tell each other and ourselves: about performativity and modernity, being and becoming, subjectivation and de-subjectivation, liminality and structure. ${ }^{26}$ In Kenya, observes Henrietta Moore (2009), reflections on cultural relativism are on the rise because Christian evangelicals have instituted something very similar to anthropological cultural relativism as foundational to local education systems they sponsor and develop. This illustrates how local "cultures" are not necessarily offshoots of global modernity, but are rather parts of one global conversation about what modernity is, and this conversation includes our "modern social theories." 27 People speak and think of their lives in terms and paradigms invented and popularized by scholarship past and present. To draw on Latour's words again, "we" may have never been modern so far as how modernity is described in social theory (2012), but some of us are modern because we use the language of social theory to describe our reality.

Studying among and with vernacular Marxists showcases these problems at their best (or worst). The developments in Kenya Moore describes are relatively recent, while in Russia a state education system has offered up modernist, sociocentric, and materialist philosophies for decades. Just as in Kenya normal talk may be about the interpretation of cultures, conversations in Russia often reflect the (very moralized) relationship between "theory" and bodily, habitual, class-delineating, and therefore quite Bourdieusian "practice" (praktika). Anthropology, in/famously, has been taking a series of "turns"- textual, practical, historical, political, and ontological, to name a few. What do you do when you study natives who are literature-centric, have historical materialism as their ontology, and were taught that everything is political? What does it mean to write on everyday social theory in a place where "everyday life" (byt) has for decades been a local construct, an object of critique, and a subject of routine conversation (see Boym 1994)?

What could the tradition of unwillingness to examine Marxian optics in Russia reveal to us? For one thing, it could lay bare how, for all of anthropology's professed efforts to listen to and communicate the salience of other worlds, many of us remain beholden to the very "panoptic" frames of reference we look to move away from. For instance, in their manifesto "Theory from the

\footnotetext{
through which their identities are constructed, and they are, therefore, "dividuals" rather than "individuals."

${ }^{26}$ The present essay joins a growing movement in English-language sociology (Beck, Giddens, and Lash 1995) that argues for more appreciation of when this happens and why it matters.

27 This argument is made, less strongly, by Newell, who writes about "modernity as bluff" (2012), and by Creed, who depicts "modernity in drag" (2011). See also Sarkisova and Shevchenko's (2010) observation of the closeness of Foucault's "biopolitical" and Elias "civilizational" views to those of their interlocutors.
} 
South" (2012), Jean and John Comaroff argued for the need to decolonize social knowledge by moving away from the canons of Western Enlightenment thought. These efforts, however useful, hinge on the practical separateness of non-Western worldviews. What happens when the people with whom we work have adopted the language of the Enlightenment, perhaps even before we have? The problem is not to show that meta-theory is always situated, or provincial; most of us agree that all theories are situated. Yet being situated does not mean being isolated: on the contrary, that very situatedness is a result of political and ethical responses to other situated theories, as the case of Soviet Marxism shows so clearly.

To avoid becoming not just treacherous translators, but also a redundant amanuensis, to our interlocutors, Bruno Latour recommends that we leave modernity to the imaginary of the masses and their social theories (and to those social theorists who still think in terms of "modernity" and its discourses.) The moral implication of this move is that as soon as an idea spreads to a "populace" we need to abandon it and build our ivory tower someplace else. Another suggestion is to collaborate or "co-produce social knowledge" with our interlocutors, as some of us have been asking for in new designs for ethnographic methods (Rabinow 2009; Ingold 2014). This is a better way to proceed, but my point is that we should always be aware of who "downloads" whose social theories, and how they do so. ${ }^{28}$ Co-producing social knowledge in virtue and not in vice requires more than just a commitment to equality. In the case of Russia it requires that we recognize our shared lineage of thought, something that, as my examples above show, many vernacular Marxists would gladly discuss. This forces the researcher to find ways to narrate others as one might hope to be narrated oneself. It goes beyond recognizing that "what people simply say" may already be more familiar to us than we suppose, to grasping that they are sharing with us their own accounts of history and philosophy that can enrich our accounts of their lives.

\footnotetext{
28 An attentive reader would notice, for instance, that my own "theory" of vernacular, hegemonic Russian Marxism is recursive because it is in itself Marxist (as well as "native"). I would agree, and I would also note that the word hegemony, gegemonia, is also familiar to "locals," being a part to the famous slogan/concept of "hegemony of the proletariat," although locally it means simply "collective power." Paradoxically, it is therefore more related to the concept of democracy than is the word "democracy" itself, which sounds rather alien. I am sure that if I used gegemonia conversationally, it would be also (mis?)understood as in itself a "structure of feeling" related to unchallenged domination. Theorizing local "culture" as a hegemony is, therefore, bound in the same awkward tautologies - and not just linguistic ones - in the place where "folk" social theories are rooted in a Marxian theory that is concerned with the ways in which hegemony works, and how humanity can, in practice, escape its hegemonic condition.
} 
Beck, Ulrich, Anthony Giddens, and Scott Lash. 1995. Reflexive Modernization: Politics, Tradition, and Aesthetics in the Modern Social Order. Stanford: Stanford University Press.

Berlant, Lauren. 2007a. Nearly Utopian, Nearly Normal: Post-Fordist Affect in La Promesse and Rosetta. Public Culture 19, 2: 273-301.

Berlant, Lauren. 2007b. Slow Death (Sovereignty, Obesity, Lateral Agency). Critical Inquiry 33: 754-80.

Bessudnov, Aleksei. 2012. 3 Grafika, kotorye Oprovergayut Mif o tom, chto v Rossii Mnogo Lyudei s Vyshchym Obrazovaniem. [The myth about the large number of Russians with higher education, and 3 graphs that challenge it]. Slon. At: https:// slon.ru/russia/6_grafikov_kotorye_oprovergayut_mif_o_tom_chto_v_rossii_mnogo lyudey_s_vysshim_obrazovaniem-808854.xhtml (accessed 12 July 2016).

Boym, Svetlana. 1994. Common Places: Mythologies of Everyday Life in Russia. Cambridge: Harvard University Press.

Brennan, Teresa. 2004. The Transmission of Affect. Ithaca: Cornell University Press.

Buck-Morss, Susan. 2000. Dreamworld and Catastrophe: The Passing of Mass Utopia in East and West. Cambridge: MIT Press.

Caldwell, Melissa. 2010. Dacha Idylls: Living Organically in Russia's Countryside. Berkeley: University of California Press.

Clément, Karine. 2015. Unlikely Mobilisations: How Ordinary Russian People Become Involved in Collective Action. European Journal of Cultural and Political Sociology 2, 3-4: 211-40.

Comaroff, Jean and John L. Comaroff. 2012. Theory from the South: Or, how EuroAmerica Is Evolving toward Africa. Anthropological Forum 22, 2: 113-31.

Creed, Gerald W. 2011. Masquerade and Postsocialism: Ritual and Cultural Dispossession in Bulgaria. Bloomington: Indiana University Press.

Crehan, Kate A. F. 2002. Gramsci, Culture and Anthropology. Berkeley: University of California Press.

Das, Veena. 2006. Life and Words: Violence and the Descent into the Ordinary. Chicago: University of Chicago Press.

Deleuze, Gilles and Félix Guattari. 1983. Anti-Oedipus. Robert Hurley, Mark Seem, and Helen R. Lane, trans. Minneapolis: University of Minnesota Press.

Donahoe, Brian and Joachim Otto Habeck, eds. 2011. Reconstructing the House of Culture: Community, Self, and the Makings of Culture in Russia and Beyond. New York: Berghahn Books.

Engelke, Matthew. 2007. A Problem of Presence: Beyond Scripture in an African Church. Berkeley: University of California Press.

Etkind, Alexander, Noah Trans Rubins, and Maria Trans Rubins. 1997. Eros of the Impossible: The History of Psychoanalysis in Russia. Boulder: Westview Press.

Fitzpatrick, Sheila. 1993. Ascribing Class: The Construction of Social Identity in Soviet Russia. Journal of Modern History 65, 4: 745-70.

Grant, Bruce. 1995. In the Soviet House of Culture: A Century of Perestroikas. Princeton: Princeton University Press.

Gregg, Melissa and Gregory J. Seigworth. 2010. The Affect Theory Reader. Durham: Duke University Press.

Hann, Chris. 2011. Moral Dispossession. InterDisciplines: Journal of History and Sociology 2, 2. At: http://www.inter-disciplines.org/index.php/indi/article/view/36 (accessed 25 Apr. 2017).

Ingold, Tim. 2014. That's Enough about Ethnography! Hau: Journal of Ethnographic Theory 4, 1: 383-95. 
Jeffrey, Craig. 2010. Timepass: Youth, Class, and the Politics of Waiting in India. Stanford: Stanford University Press.

Kalinin, Il'ya. 2012. Ugnetennye Dolzhny Govorit' (Massovyi Prizyv v Literaturu I Formirovanie Sovetskogo Sub'ekta, 1920e-Nachalo 1930kh Godov). [Subalterns must speak (on the mass call to join the literary circles, and the formation of Soviet subject from the 1920s-early 1930s)]. In Alexander Etkind, Ilya Kukulin, and Dmitry Ufel'man, eds., Praktiki Vnutrennei Kolonizatsii v Kul'turnoi Istorii Rossii [Practices of internal colonization in the cultural history of Russia]. Moscow: Novoe Literaturnoe Obozrenie, 587-663.

Keane, Webb. 2007. Christian Moderns: Freedom and Fetish in the Mission Encounter. Berkley: University of California Press.

Kelly, Catriona. 2001. Refining Russia: Advice Literature, Polite Culture, and Gender from Catherine to Yeltsin. Oxford: Oxford University Press.

Kelly, Catriona. 2002. 'A Laboratory for the Manufacture of Proletarian Writers': The Stengazeta (Wall Newspaper), Kul'turnost' and the Language of Politics in the Early Soviet Period. Europe-Asia Studies 54, 4: 573-602.

Kharkhordin, Oleg. 1999. The Collective and the Individual in Russia: A Study of Practices. Berkeley: University of California Press.

Kotkin, Stephen. 1997. Magnetic Mountain: Stalinism as a Civilization. Berkeley: University of California Press.

Kruglova, Anna. 2013. Sensory Utopia in the Times of "Cultural Revolution": On Art, Public Space, and the Moral Ontology of Class. Laboratorium 5, 1: 25-51.

Kruglova, Anna. 2016. Anything Can Happen: Everyday Morality and Social Theory in Russia. PhD diss., University of Toronto.

Kruglova, Anna. n.d. Between 'Too Young' and 'Already Old': The Fleeting Adulthood of Perestroika Teens. In Deborah Durham and Jaqueline Solway, eds., Elusive Adulthood: The Anthropology of New Maturities. Bloomington: Indiana University Press (expected Nov. 2017).

Lambek, Michael. 1998. Body and Mind in Mind, Body and Mind in Body: Some Anthropological Interventions in a Long Conversation. In Michael Lambeck and Andrew Strathern, eds., Bodies and Persons: Comparative Perspectives from Africa and Melanesia. Cambridge: Cambridge University Press, 103-23.

Lambek, Michael. 2008. Value and Virtue. Anthropological Theory 8, 2: 133-57.

Latour, Bruno. 2005. Reassembling the Social: An Introduction to Actor-Network Theory. Oxford: Clarendon Press.

Latour, Bruno. 2012. We Have never Been Modern. Cambridge: Harvard University Press.

Lemon, Alaina. 2004. 'Dealing Emotional Blows': Realism and Verbal 'Terror' at the Russian Theatrical Academy. Language \& Communication 24: 313-37.

Lemon, Alaina. 2008. Hermeneutic Algebra: Solving for Love, Time/Space, and Value in Putin-Era Personal Ads. Journal of Linguistic Anthropology 18, 2: 236-67.

Lemon, Alaina. 2009. Sympathy for the Weary State? Cold War Chronotopes and Moscow Others. Comparative Studies in Society and History 51, 4: 832-64.

Lemon, Alaina. n.d. Technologies for Intuition: Cold War Circles and Telepathic Rays. Berkeley: University of California Press (expected Nov. 2017).

Lenin, Vladimir I. 1972 [1920]. "Left-Wing” Childishness. In Collected Works. Vol. 27. 4th English ed. Moscow: Progress Publishers, 323-34.

Lerner, Julia. 2011. TV Therapy without Psychology: Adapting the Self in Post-Soviet Media. Laboratorium 3, 1: 178-80.

Luehrmann, Sonja. 2011. Secularism Soviet Style: Teaching Atheism and Religion in a Volga Republic. Bloomington: Indiana University Press. 
Magun, Artemy. 2014. Negativity in Communism: Ontology and Politics. Russian Sociological Review 13, 1: 9-25.

Mains, Daniel. 2007. Neoliberal Times: Progress, Boredom, and Shame among Young Men in Urban Ethiopia. American Ethnologist 34, 4: 659-73.

Masquelier, Adeline. 2013. Teatime: Boredom and the Temporalities of Young Men in Niger. Africa 83, 3 (2013): 470-91.

Massumi, Brian. 2002. Parables for the Virtual: Movement, Affect, Sensation. Durham: Duke University Press.

Matza, Tomas. 2010. Subjects of Freedom: Psychology, Power and Politics in Postsocialist Russia. PhD diss., Stanford University.

Mazzarella, William. 2009. Affect: What Is It Good For? In Saurabh Dube, ed., Enchantments of Modernity: Empire, Nation, Globalization. Emeryville, Calif.: Alibris, 291-309.

Moore, Henrietta. 2009. Epistemology and Ethics: Perspective from Africa. Social Analysis 53, 2: 207-18.

Muehlebach, Andrea. 2012. The Moral Neoliberal: Welfare and Citizenship in Italy. Chicago: University of Chicago Press.

Nafus, Dawn. 2006. Post-Socialism and the Notions of Context in St. Petersburg. Journal of the Royal Anthropological Institute 12: 607-24.

Nemtzev, Michail. 2015. K Istorii Sovetskoi Akademicheskoi Distsipliny 'Osnovy Nauchnogo Kommunizma' [On the history of Soviet academic discipline 'foundations of scientific communism']. Idei i idealy 1, 27: 23-38.

Newell, Sasha. 2012. The Modernity Bluff: Crime, Consumption, and Citizenship in Côte d'Ivoire. Chicago: University of Chicago Press.

Patico, Jennifer. 2005. To Be Happy in a Mercedes: Tropes of Value and Ambivalent Visions of Marketization. American Ethnologist 32, 3: 479-96.

Patico, Jennifer. 2008. Consumption and Social Change in a Post-Soviet Middle Class. Washington, D.C.: Woodrow Wilson Center Press.

Rabinow, Paul. 2009. Marking Time: On the Anthropology of the Contemporary. Princeton: Princeton University Press.

Ries, Nancy. 1997. Russian Talk: Culture and Conversation during Perestroika. Ithaca: Cornell University Press.

Ries, Nancy. 2009. Potato Ontology: Surviving Postsocialism in Russia. Cultural Anthropology 24, 2: 181-212.

Roseberry, William. 1988. Political Economy. Annual Review of Anthropology 17: 161-85.

Sarkisova, Olga and Olga Shevchenko. 2010. Between Elias and Foucault: Discipline, Photography, and the Soviet Childhood. Social Psychology Quarterly 73, 1: 1-4.

Scott, James C. 1998. Seeing Like a State: How Certain Schemes to Improve the Human Condition Have Failed. New Haven: Yale University Press.

Sedgwick, Eve Kosofsky and Adam Frank. 2003. Touching Feeling: Affect, Pedagogy, Performativity. Durham: Duke University Press.

Shevchenko, Olga. 2009. Crisis and the Everyday in Post-Socialist Moscow. Bloomington: Indiana University Press.

Ssorin-Chaikov, Nikolai. 2017. Two Lenins: A Brief Anthropology of Time. Chicago: University of Chicago Press.

Stewart, Kathleen. 2007. Ordinary Affects. Durham: Duke University Press.

Strathern, Marilyn. 1988. The Gender of the Gift: Problems with Women and Problems with Society in Melanesia. Berkeley: University of California Press.

Sykes, Karen. n.d. Inventing the Rules: Redefining Moral Agency amongst the First Post-Independence Generation in Papua New Guinea. In Deborah Durham and 
Jaqueline Solway, eds., Elusive Adulthood: The Anthropology of New Maturities. Bloomington: Indiana University Press (expected Nov. 2017).

Taussig, Michael. 1980. The Devil and Commodity Fetishism in Latin America. Chapel Hill: University of North Carolina Press.

Utrata, Jennifer. 2015. Women without Men: Single Mothers and Family Change in New Russia. Ithaca: Cornell University Press.

Verdery, Katherine. 1996. What Was Socialism, and what Comes Next? Cambridge: Cambridge University Press.

Williams, Raymond. 2015 [1979]. Politics and Letters: Interviews with New Left Review. New York: Verso Books.

Yurchak, Alexei. 2005. Everything Was Forever until It Was no More: The Last Soviet Generation. Princeton: Princeton University Press.

Zdravomyslova, Elena and Anna Temkina. 2002. Krizis Maskulinnosti v Pozdnesovetskom Diskurse. [The crisis of masculinity in the late-Soviet discourse]. In Sergey Ushakine, ed., O Muzhe(n)stevennosti [On masculinity]. Moscow: Novoe Literaturnoe Obozrenie, 432-52.

Žižek, Slavoj. 1989. The Sublime Object of Ideology. New York: Verso Books.

\begin{abstract}
Scholars have long tracked how the USSR, a laboratory of social engineering, was deeply informed by local readings of Marxist social theory. Why, then, in recent years, have so many historical and anthropological studies of Russia excluded "Marxist" from the list of main descriptors, or optics, through which they view their material? In this essay, I argue that in much contemporary scholarship Marxism and its many afterlives have evidenced a kind of blind spot, reducing Marxism to "just" an ideology. I assert that rediscovering the presence of Marxism in Russia as a Gramscian hegemonic process and a vernacular that emerged among "laymen" can help us understand how a wide range of Russians continue to make sense of their worlds today. Drawing on several years of research in the city of Perm, I interpret everyday conversations among middle-age urbanites about morality, and demonstrate how this rediscovery of Marxism can elucidate what things matter for Russians today, and how. If social scientists proceed by acknowledging that "professional" and "lay" social knowledge increasingly share sources of "theoretical" inspiration, then we face a range of narrative challenges.
\end{abstract}

Key words: ethics, epistemology, affect, materialism, Marxism-Leninism, Russia, postsocialism, generation, hegemony 